$3(30) / 2015$

\author{
Ewa Szatan \\ Uniwersytet Gdański \\ ewaszatan@poczta.onet.pl
}

\title{
Myśli Jana Jakuba Rousseau o wychowaniu i muzyce - ich reminiscencje w rytmice Emila Jaques-Dalcroze'a
}

\section{Summary \\ Thoughts of Jean-Jacques Rousseau on education and music - their reminiscences in Dalcroze Eurhythmics}

The text is an attempt to analyze and interpret a selection of Jean-Jacques Rousseau's thoughts about education relating to music education, the thoughts that I find as reminiscences of assumptions and methods of Emil Jaques-Dalcroze. He focuses his discourse on the issues related to the moment when the musical education of the child takes form and also on the quality of the child's first contacts with music, and the role of parent and teacher in the child's appreciation of music. A comparison of the assumptions regarding musical education of Rousseau and Jaques-Dalcroze may seem interesting, because, despite the passage of successive decades, they seem to be still valid, as, for example, the one that speaks of the joy of discovery that should accompany the child in the learning process.

Słowa kluczowe: dziecko, nauczyciel, muzyka, wychowanie muzyczne, rytmika.

Keywords: child, teacher, music, musical education, eurythmics.

\section{Wstęp}

Jan Jakub Rousseau - filozof, literat, wychowawca, człowiek o wielu zainteresowaniach, muzyk-amator, muzyk-samouk. Emil Jaques-Dalcroze - dobrze wykształcony muzyk, kompozytor, pianista, dyrygent, aktor, pedagog, twórca rytmiki ${ }^{1}$. Co łączy tych dwóch obywateli Genewy, poza miejscem, w którym przez lata ogniskowało się ich życie i aktywność

\footnotetext{
1 Rytmika - metoda kształcenia muzycznego, którą stworzył E. Jaques-Dalcroze; obejmuje rytmikę, solfeż i improwizację fortepianową. Najważniejsze cele metody (poza rozwojem muzycznym) według jej twórcy to: „rozwijanie wrażliwości muzycznej w całym organizmie, tworzenie poczucia porządku i równowagi po obudzeniu wszystkich możliwości motorycznych, rozwijanie wyobraźni" (Brzozowska-Kuczkiewicz 1991: 32). W Polsce rytmika jest częścią kształcenia muzycznego w podstawowym i średnim szkolnictwie muzycznym. W wyższym szkolnictwie muzycznym kształci się nauczycieli rytmiki. W przedszkolach i szkołach ogólnokształcących w edukacji muzycznej wykorzystuje się wybrane elementy rytmiki. Rytmika jest wykorzystywana w muzykoterapii aktywnej (logorytmika). Metoda jest znana na całym świecie. W obecnym 2015 roku obchodzono 150 rocznicę urodzin E. Jaques-Dalcroze'a. Więcej o metodzie można przeczytać w Pismach wybranych E. Jaques-Dalcroze'a, publikacjach M. Brzozowskiej-Kuczkiewicz, Z. Burowskiej, M. Przychodzińskiej, M. Skazińskiej i in.
} 
zawodowa? Żyli w różnych epokach - pierwszy urodził się i zmarł w XVIII wieku, drugi urodził się w drugiej połowie XIX wieku, a zmarł w połowie XX. Osobiście nie mogli się spotkać, ale uwagi o wychowaniu i muzyce pierwszego były bliskie drugiemu i mogły inspirować Jaques-Dalcroze’a przy wypracowaniu własnej koncepcji wychowania muzycznego ${ }^{2}$. Każdy z nich wpisał się w określony sposób w historię muzyki i historię wychowania. Obszarami wspólnymi zainteresowania obu Szwajcarów była muzyka i było dziecko.

Myśli muzyczne i idee pedagogiczne Jana Jakuba Rousseau pozostawione w jego dorobku literackim (Skowron 2010) niewątpliwie znane były Emilowi Jaques-Dalcroze'owi, który w swoich tekstach muzycznych i dziełach pedagogicznych powoływał się na tezy oświeceniowego filozofa, m.in. na tezę uniwersalną, a bardzo istotną także dla współczesnego wychowania muzycznego, mówiącą o tym, że edukacja człowieka rozpoczyna się wraz z jego przyjściem na świat i jest procesem determinowanym środowiskowo (Jaques-Dalcroze 1992: 27)33. Czasy, w których żył i pracował nad swoją koncepcją gimnastyki rytmicznej ${ }^{4}$ E. Jaques-Dalcroze sprzyjały nowatorskiej pracy, co więcej, jego osiągnięcia były weryfikowane przez współczesnych mu psychologów i pedagogów ${ }^{5}$. Spoglądając na to z perspektywy kolejnego stulecia, dostrzegając fenomen rytmiki Jaques-Dalcroze'a (jej znaczenie nie tylko dla kształcenia muzycznego, lecz także terapii), należy potwierdzić trafność jej założeń. Dlatego w tekście chciałabym przywołać cztery główne tezy Rousseau (w dalszej części tekstu przedstawiam je jako: Myśl 1, Myśl 2, Myśl 3, Myśl 4), które są fundamentalne dla Dalcrozowskiej koncepcji wychowania muzycznego, dla rytmiki:

1. Od momentu narodzin powinno się dbać o rozwój umysłowy i fizyczny dziecka (w rytmice aktywność muzyczna pobudza i akceleruje rozwój procesów poznawczych i sprawność fizyczną - przypis autorki).

2. Matka jest naturalną opiekunką dziecka i inicjatorką jego pierwszych doświadczeń muzycznych.

3. Dziecko powinno być samodzielne w myśleniu (także w myśleniu muzycznym), samo może odkrywać świat (świat muzyki) i prawa nim rządzące (np. zasady muzyki, sposób interpretowania muzyki), nauczyciel ma tylko je w tym wspierać.

4. Dziecko powinno znajdować przyjemność i radość w uczeniu się (uczeniu się muzyki).

Swoje głębokie przemyślenia Rousseau zapisał w traktacie Emil, czyli o wychowaniu, (Rousseau 1955a: 33-37, 128-129, 172-176). W niniejszym tekście będą one (idee

2 E. Jaques-Dalcroze powołuje się na różne przemyślenia J.J. Rousseau - np. w Pismach wybranych, s. 27.

3 Jaques-Dalcroze cytuje fragmenty zapisane w traktacie Emil, czyli o wychowaniu J.J. Rousseau. Znaczenie wczesnego uczenia muzyki potwierdzają także inne osiągnięcia, np. szkoły S. Suzuki w zakresie nauki gry na skrzypcach.

4 Termin ,gimnastyka rytmiczna” początkowo stosował dla swojej metody sam jej twórca. Później pozostała skrócona nazwa „rytmika”. Dlatego w tekście będę posługiwała się nimi wymiennie.

5 Jaques-Dalcroze był bardzo zainteresowany pracami Ruchu Nowego Wychowania. Znał m.in. É. Claparède (współzałożyciela utworzonego w dwusetną rocznicę urodzin J.J. Rousseau Instytutu jego imienia) i jego prace. Doceniał także osiągnięcia pedagogiczne M. Montessori. 
J.J. Rousseau) zakotwiczone w edukacji muzycznej, będą odnosiły się do koncepcji rytmiki Emila Jaques-Dalcroze’a.

\section{Jan Jakub Rousseau i Emil Jaques-Dalcroze - fakty z życia wyjaśniające ich filozoficzno-pedagogiczne rozważania o wychowaniu muzycznym}

Jan Jakub Rousseau i Emil Jaques-Dalcroze część swojego życia spędzili w Genewie. Obaj byli ważnymi i nietuzinkowymi jej obywatelami. W okresie dzieciństwa pierwszy wychowywał się bez matki, gdyż zmarła ona kilka dni po jego narodzinach, ale w pewnym stopniu zastępowała ją w wychowaniu ciotka, siostra ojca, bardzo wrażliwa na muzykę i jak wspomina ją J.J. Rousseau, chętnie i często śpiewająca piosenki (Rousseau 1978). Trudno ocenić, czy wychowanie przez matkę biologiczną miałoby taki sam wpływ na rozwój muzyczny Jana Jakuba oraz na reprezentowane w życiu dorosłym poglądy na temat muzyki i wychowania muzycznego. Drugiemu (Emilowi) dzieciństwo upływało pod opieką matki kochającej i troskliwej. Wspólne było to, że jako chłopcy wychowywali się w kontakcie z muzyką, co w znacznej mierze ukształtowało ich wrażliwość, a przede wszystkim wyznaczyło kierunek przyszłej aktywności zawodowej.

Wrażliwość na muzykę i zainteresowanie się nią Jana Jakuba Rousseau ukształtowało środowisko - w pierwszych latach życia głównie rodzinne. Ojciec jego, jak większość Szwajcarów, zajmował się zegarmistrzostwem, ale z zamiłowania był nauczycielem tańca. Być może, to dzięki ojcu i jego aktywności muzycznej syn Jan Jakub wykazywał dość wcześnie zainteresowanie muzyką. Można założyć, że prawdopodobnie także dzięki ciotce Suzanne doświadczał pierwszych spontanicznych i naturalnych wrażeń muzycznych ${ }^{6}$. To ona wzbudziła pasję Jana Jakuba do muzyki, ,upodobanie albo raczej namiętność" (Rousseau 1978: 11), gdy nuciła małemu bratankowi wiele piosenek ,głosikiem pełnym słodyczy", jak pisał o tym dojrzały już Rousseau w Wyznaniach (Rousseau 1978: 11).

Środowisko rodzinne małego Emila Jaques'a ${ }^{7}$ bardzo sprzyjało rozwojowi zamiłowania do muzyki. Wychowywał się $\mathrm{w}$ rodzinie raczej zamożnej ${ }^{8} \mathrm{i}$ o bogatych tradycjach muzycznych (niemal wszyscy członkowie zawodowo lub amatorsko grali na różnych instrumentach i śpiewali, zajmowali się muzyką), a od szóstego roku życia pobierał regularne lekcje gry na fortepianie. Już wtedy tworzył swoje pierwsze kompozycje na fortepian (Brzozowska-Kuczkiewicz 1991: 12). Zainteresowanie Emila muzyką z jednej strony wynikało z kultywowania rodzinnych tradycji, z drugiej - ,z obcowania z wielką kulturą

\footnotetext{
6 Przywołując badania z zakresu zdolności muzycznych, należy stwierdzić, że największe znaczenie dla ich rozwoju mają pierwsze lata życia dziecka (B. Kamińska, K. Lewandowska, M. Manturzewska, B. Tiepłow, J. Wierszyłowski i in.).

7 Jaques - to rodowe nazwisko Emila; pseudonim artystyczny Dalcroze przyjmuje w 1886 roku. Więcej na ten temat można przeczytać w: E. Jaques-Dalcroze, Pisma wybrane, Warszawa 1992, s. 166.

8 Podobnie jak w rodzinie Rousseau, ojciec Emila zajmował się zegarmistrzostwem, ale był przedstawicielem firmy genewskiej w Wiedniu, stąd kilka pierwszych lat dzieciństwa Emil wychowywał się właśnie tam.
} 
Wiednia" (Brzozowska-Kuczkiewicz 1991: 12) ${ }^{9}$. Od dzieciństwa rozwijał swoje zainteresowania sztuką i jako młodzieniec uczył się równolegle muzyki w konserwatorium genewskim, a na uniwersytecie studiował sztuki teatralne. Uzyskał gruntowne wykształcenie w obu kierunkach, stąd profesjonalnie zajmował się komponowaniem piosenek, utworów fortepianowych i operetki oraz przez jakiś czas pisaniem sztuk teatralnych. Swoje pierwsze występy muzyczne odnotował jako sukcesy. Jeszcze przed trzydziestym rokiem życia podjął pracę w konserwatorium w Genewie i uczył tam przez wiele lat harmonii teoretycznej i solfeżu. Instytucja ta w owych czasach była dość konserwatywna w swych zasadach kształcenia, co skłania do przypuszczeń, że tym bardziej oświeceniowe idee Jana Jakuba Rousseau, jak i współczesne założenia Ruchu Nowego Wychowania, musiały poruszyć twórczego i kreatywnego Emila Jaques-Dalcroze'a, poszukującego dla swojej gimnastyki rytmicznej uzasadnień we współczesnej myśli pedagogicznej i psychologicznej. Niełatwo było mu mierzyć się z władzami konserwatorium, gdy zaczął eksperymenty z rytmiką, ale po latach doświadczeń pedagogicznych jednak to właśnie Jaques-Dalcroze'owi powierzono zadanie zreformowania programów nauczania solfeżu. To tylko niektóre fakty $\mathrm{z}$ jego życia ${ }^{10}$.

Losy Jana Jakuba były odmienne - młody Rousseau nie kształcił się muzycznie w konserwatorium jak Emil Jaques-Dalcroze. W rodzinnej Genewie, w czasach oświecenia, brakowało atmosfery kultury muzycznej, a trendy w muzyce wyznaczał Kościół. Ascetyczna doktryna J. Kalwina, w przeciwieństwie do poglądów M. Lutra, nie zezwalała na użycie w kościele instrumentów, w ten sposób blokując dostęp do muzyki instrumentalnej, do nowych gatunków i form muzycznych (Górny 2012, Skowron 2010). Tak więc, można przypuszczać, że Rousseau jako dziecko nie miał warunków do regularnej nauki muzyki, a tym samym ograniczony był proces rozwoju jego muzycznych zdolności. Gdy miał pięć lat, powstało w mieście świeckie towarzystwo muzyczne, które mogło być szansą poszerzenia muzycznej oferty edukacyjnej, ale rozwiązano je po trzech latach (kalwiniści widzieli w świeckiej muzyce zagrożenie dla pobożności wiernych). Równolegle, w tym samym czasie, M. Luter przyznawał muzyce bardzo ważne miejsce w liturgii, dzięki czemu w Europie rozkwitała niemiecka muzyka organowa J.S. Bacha. (Bem, Makowski 2009, Górny 2012, Skowron 2010). Uważam wobec tego, że w tak niesprzyjającym historyczno-polityczno-muzycznym klimacie Jan Jakub Rousseau zapewne nie mógł poznawać muzyki instrumentalnej, nie mógł rozsmakowywać się w bachowskiej polifonii i kontrapunkcie. Nawet powszechnie dostępna muzyka wokalna miała ograniczony zakres, treść i formę. Prawdopodobnie te zdarzenia zaciążyły na mniej dynamicznym rozwoju muzycznym Rousseau i na jego późniejszych poglądach na temat muzyki. Inne natomiast fakty z jego życia ciągle jednak były powiązane z pierwszymi dziecięcym doświadczeniami,

\footnotetext{
9 E. Jaques-Dalcroze także kilka lat swego dorosłego życia spędził m.in. ponownie w Wiedniu, na studiach muzycznych oraz w Paryżu.

${ }^{10}$ Więcej o życiu Jaques-Dalcroze'a można przeczytać np. w: M. Brzozowska-Kuczkiewicz, Emil Jaques-Dalcroze i jego rytmika. Warszawa1991, WSiP czy L. Choksy, R.M Abramson., A.E Gillespie., D. Woods, Teaching music in the twentieth century, New Jersey1986, Prentice Hall.
} 
które uwrażliwiły go na śpiew i piękno melodii (był to kontakt ze sztuką spontaniczny a zarazem naturalny), co dostrzec można w podejmowanej przez Rousseau polemice na temat opery (Rousseau 1978, Skowron 2010).

Jan Jakub Rousseau jako kilkunastoletni młodzieniec wyjechał z rodzinnego miasta, a zbieg różnych okoliczności sprawił, że sam jednak zaczął zgłębiać tajniki muzyki (m.in. zapoznaje się z notacją muzyczną i kopiuje nuty) i to ona stała się źródłem jego utrzymania. Poza Genewą pierwszy raz zetknął się z muzyką w jej różnorodnych przejawach i formach, poznał zarówno włoską muzykę wojskową graną podczas parad, jak i muzykę „wysoką” wykonywaną przez Kapelę królewską (Rousseau 1978, Skowron 2010). Na jego drodze od tej pory pojawiali się muzycy różnych narodowości, przy których doskonalił swe muzyczne umiejętności i dojrzewał muzycznie, dojrzewały także jego poglądy na muzykę. Jednak pierwsza kompozycja na zamówienie i pierwszy koncert przed publicznością Lozanny zdemaskowały jego brak wykształcenia muzycznego i skończyły się pośmiewiskiem, ale... spowodowały mobilizację i podjęcie muzycznych studiów. Po kilku latach jego muzyka zachwyciła dwór królewski, a fakt ten autor Wyznań opisuje słowami: „Biedny Janie Jakubie! W tym okrutnym momencie (pierwszego publicznego nieudanego występu dyrygowania własną kompozycją - przypis autorki) nie spodziewałeś się pewnie, iż pewnego dnia, wobec króla Francji i całego dworu, tony twoje wywołają szmer zdumienia i oklask zachwytu i że we wszystkich lożach urocze kobiety będą szeptały półgłosem: Cóż za czarowne dźwięki! Co za boska muzyka! Jak te melodie wnikają do serca!" (Rousseau 1978: 185) ${ }^{11}$.

\section{Rozważania Jana Jakuba Rousseau i Emila Jaques-Dalcroze'a o wychowaniu muzycznym}

Jan Jakub Rousseau przebył długą drogę od swoich pierwszych dziecięcych doświadczeń z muzyką, i jak sam pisał, „od namiętności do muzyki graniczącej z szałem” (Rousseau 1962: 30). Tak samo długą - do naukowego zajmowania się muzyką i do dyskusji o wychowaniu muzycznym człowieka. Jako muzyk, ale jednak bardziej filozof i muzyk-amator był wolny od akademickiej rutyny. Ale właśnie to pozwalało mu na podejście do wielu zagadnień w sposób dość niekonwencjonalny, jak na owe czasy i nowatorski. Jego dyskurs filozoficzny w sporze o operę, w który się włączył, był odebrany trochę jako prowokacja intelektualna, nie tylko odnosząca się do aspektów natury estetycznej, ale także politycznej. Z kolei opracowanie haseł muzycznych dla francuskiej encyklopedii było wyrazem jego przekonania o ,ekspresyjnej sile melodii w utworach muzycznych” (Skowron 2010: 10). Wiele z idei, które ogniskował J.J. Rousseau wokół zagadnień muzyki, czyli m.in. język muzyki w operze, ekspresja języka, notacja muzyczna, zawarte w jego testamencie

\footnotetext{
${ }^{11}$ Na początku J.J. Rousseau zaczął się nawet wzorować na jednym z muzyków i nie zważając na niedostatki w swoim wykształceniu muzycznym, zaczął się przedstawiać jako nauczyciel muzyki i kompozytor. Celowo zmienił przy tym nazwisko na Vaussore poprzez anagram nazwiska rodowego Rousseau, by nie być rozpoznawalnym. Miał świadomość swoich niedostatków, gdy pisał o tym w Wyznaniach.
} 
muzycznym (Skowron 2010: 159) i niektóre z idei wychowania (wyrażane w Emilu i Wyznaniach), wywarły wpływ na współczesną dydaktykę muzyczną ${ }^{12}$.

150. rocznica urodzin Emila Jaques-Dalcroze'a to znakomita okazja, by przypomnieć niektóre myśli twórcy rytmiki, dla którego idee wychowawcze i myśl muzyczna oświeceniowego filozofa Jana Jakuba Rousseau stanowiły inspiracje lub były potwierdzeniem słuszności tez dotyczących wychowania-kształcenia rytmicznego. Punktem wyjścia do przeprowadzenia analizy ich poglądów niech będzie cytat twórcy rytmiki:

Jest znacznie więcej muzykalnych dzieci niż wydaje się to rodzicom. (...) Zdolność do muzyki jest bardzo często w dziecku głęboko ukryta i z takiego czy innego powodu nie znajduje ona sposobu, w jaki mogłaby się objawić. (...) Rolą edukacji jest więc wyjście naprzeciw muzykalności dziecka (Jaques-Dalcroze 1992: 25).

„Wychodzenie naprzeciw muzykalności dziecka” według E. Jaques-Dalcroze’a to założenie, że zdolności muzyczne ${ }^{13}$ należy rozwijać poprzez aktywność muzyczną i ten proces ma się zacząć jak najwcześniej w życiu dziecka, czyli jest to pole dla świadomie realizowanej edukacji dziecka przez rodziców i nauczycieli. Rytmika może być tego przykładem, gdyż równolegle z dbałością o rozwój muzykalności (a więc zmysłów, a poprzez odpowiednie bodźcowanie - umysłu) pobudza się rozwój ruchowy i paralelnie, ukierunkowana aktywność ruchowa stymuluje procesy poznawcze (Shuter-Dyson, Gabriel 1986). Na tę zależność wskazuje także Jan Jakub Rousseau: „Zapoczątkowanie wychowania umysłowego w tym czasie musi iść w parze z rozwojem fizycznym dziecka. Jeśli chcesz rozwijać umysł dziecka, rozwijaj w nim siły, którymi umysł powinien kierować. Ćwicz bez przerwy jego ciało; uczyń je silnym i zdrowym, ażeby go uczynić roztropnym i rozumnym" (Rousseau 1955a: 128).

Poddając analizie wybrane myśli Jana Jakuba Rousseau i Emila Jaques-Dalcroze'a o wychowaniu muzycznym, które opisuję w kolejnych fragmentach tekstu (Myśli 1-4), wyróżniam w nich kategorie, które są wspólne dla obu autorów, są to: czas i sposoby przybliżania dziecka do muzyki, formy edukacji muzycznej i źródła muzycznej ekspresji, nauka muzyki i rola matek w tym procesie, związek muzyki z rozwojem poznawczym, samodzielność dziecka w percepcji muzyki, pierwsze muzyczne doświadczenia, nauczyciel - kompetentny przewodnik dziecka w świecie muzyki.

\footnotetext{
${ }^{12}$ Jednym z pomysłów Rousseau było dokonanie zmiany w dotychczasowej notacji muzycznej, która miałaby ułatwić odczytywanie nut. Koncepcję tę w 1742 przedstawił paryskiej Akademii Nauk, ale nie została ona wdrożona - nadal pozostawiając zapis nut na pięciolinii Gwidona z Arezzo. Zaproponowany przez Rousseau system zapisu dowodzi, iż potrafił on doskonale połączyć myślenie matematyczne $\mathrm{z}$ celami pragmatycznymi, kierując się w stronę praktyki muzycznej z zamiarem ułatwienia nauki w tej dziedzinie.

${ }^{13}$ Zdolności muzyczne wg podziału M. Manturzewskiej, K. Lewandowskiej.
} 


\section{Myśl 1. Od momentu narodzin powinno się dbać o rozwój umysłowy i fizyczny dziecka (aktywność muzyczna wspiera rozwój procesów poznawczych)}

Muzyczne wychowanie dziecka, a tym samym rozwój jego zdolności muzycznych, zależy od jakości i intensywności pierwszych kontaktów z muzyką (Lewandowska 1978). Powinny być one jak najwcześniejsze i na tyle przyjemne dla dziecka, by mogły w każdym momencie przerodzić się w regularną naukę muzyki. Reguła ta dotyczy rozwoju różnych zdolności, nie tylko muzycznych. Można ją odnieść do rozwoju zdolności plastycznych, językowych, sportowych itp. Rousseau wskazywał, że „wychowanie człowieka rozpoczyna się wraz z jego urodzeniem.” (Rousseau 1955a: 46). To znaczy, że także wychowanie estetyczne, w tym muzyczne. Ale od urodzenia dziecko powinno zaledwie być uczonym, jak „miłować” muzykę, co można interpretować jako „nauczyć je bycia wrażliwym” na muzykę i rozwijać jego muzyczną wyobraźnię (tak jak oddziaływało na małego Jana Jakuba śpiewanie ciotki Suzanne), by potem samo mogło zgłębiać tajniki wiedzy muzycznej (Rousseau 1962: 151-152).

Rozwijanie umiejętności muzycznych i wiedzy według Rousseau odbywa się poprzez dwa rodzaje aktywności: „Ażeby dobrze znać muzykę, nie wystarcza odtwarzać ją, trzeba ją tworzyć; przy czym jednego uczyć się trzeba razem z drugim, inaczej bowiem nie zna się jej nigdy dobrze" (Rousseau 1955a: 175). Tworzenie muzyki z natury jest samoistnym aktem dziecka, natomiast do drugiego - odtwarzania, musi być przygotowane poprzez naukę czytania nut, której Rousseau nie chce zanadto narzucać dziecku: „Rozumie się, że nie spiesząc się bynajmniej z nauką czytania pisma, nie będę się spieszył z nauką czytania nut" (Rousseau 1955a: 174). Jan Jakub Rousseau jednak zauważał pewną różnicę pomiędzy procesem czytania liter a znaków muzycznych. Pierwszy, czyli czytanie liter „męczyło zbytnio uwagę”, natomiast znajomość nut była potrzebna, gdyż pozwalała na „oddawanie myśli innych” (Rousseau 1955a: 173-174). Rousseau dopuszczał naukę muzyki, ale głównie odnosił ją do wtajemniczania dziecka w sposoby śpiewania solfeżu nazwami literowymi i solmizacyjnymi. Aby uprościć tę naukę, proponował nowy system zapisu nut, odmienny od dotychczasowego systemu Gwidona z Arezzo ${ }^{14}$. Nauka solfeżu miała jednak dotyczyć wszystkiego, co wiąże się z ekspresją śpiewania (co zauważa się także m.in. w jego sporze o operę), i niekoniecznie miała służyć graniu na instrumencie. Dziecięce doświadczenia śpiewu wielokrotnie przywoływanej w tym tekście ciotki Suzanne mogły spowodować entuzjazm Rousseau do melodyki jako głównego źródła muzycznej ekspresji, mającej na celu przede wszystkim wyrażanie uczuć.

Oświeceniowy filozof i muzyk-samouk odwołuje się także do sposobów śpiewania solfeżu przez dziecko, prezentując wstępne uwagi do notacji muzycznej, którą stworzył, ale nie wprowadził w użycie. Będąc jednak matematykiem, musiał zauważać na własnym przykładzie, że zajmowanie się muzyką, także jej stroną teoretyczną, rozwija myślenie i wyobraźnię.

${ }^{14}$ Szczegółowo system opisany został w książce Z. Skowrona Myśl muzyczna Jeana Jacques 'a Rousseau, s. $47-87$. 
Zapewne takie podejście Rousseau do nauki muzyki mogło być w pewnym stopniu inspirujące dla Jaques-Dalcroze'a, który sam, od wczesnego dzieciństwa poznawał tajniki wiedzy muzycznej, a jako pedagog-muzyk wiedział, że notację muzyczną należy poznawać równolegle do słuchania i śpiewania, ale także grania na instrumencie. $\mathrm{W}$ edukacji muzycznej znajomość nut jest ważna i powinna być wynikiem potrzeby i możliwości wyrażenia muzyki przez dziecko, jednak dopiero wówczas, gdy dziecko jest już wrażliwe na muzykę.

I tutaj można się dopatrzeć wspólnego dla Jana Jakuba Rousseau i Emila Jaques-Dalcroze'a myślenia o improwizowaniu muzyki. Już we wczesnym dzieciństwie obserwowane spontaniczne śpiewanie, granie czy poruszanie się zgodne z muzyką może być uznane za przejaw muzykalności. Może prowadzić do zaciekawienia dziecka i dopiero wówczas do chęci poznawania przez nie znaków - nut służących do zapisu tego, co samemu się wcześniej wykonało. „W istocie swej muzyka jest językiem, a każdy język musi przekazać myśl wraz ze wszystkimi niuansami w momencie, gdy zachodzi taka potrzeba - jutro, jeśli myśl może poczekać, dzisiaj i natychmiast, jeśli trzeba ją wyrazić szybko i w pełni. (...) Muzykalność wymaga różnorodnych przymiotów - żywej wrażliwości na dźwięki i rytmy, poczucia metrum i wyczucia niuansów ${ }^{15}$. Wszystkie te cechy można rozwinąć w stopniu, jakiego sobie na ogół wcale nie wyobrażamy. Jeśli chodzi jednak o wrażliwość i wyobraźnię, ich kształcenie należy rozpocząć jak najwcześniej” (Jaques-Dalcroze 1992: 143). W tym cytacie Jaques-Dalcroze'a uchwycić można wyraźne podobieństwo do myśli Rousseau.

Emil Jaques-Dalcroze miał dość bliski kontakt z jemu współczesnymi psychologami. W swoich pracach przywoływał m.in É. Claparède'a. Rozumiał, że wnikliwa obserwacja dzieci pozwoli na wypracowanie pewnych zasad (połączenia sfery ruchu z pracą intelektualną człowieka), które stały się podstawą jego rytmiki. Stosowanie określonych reguł uważał za naturalne, bo były powiązane $\mathrm{z}$ rytmem, a rytm organizuje porządek w muzyce (i nie tylko) i jak pisał: „Rytm stanowi podstawę każdej sztuki. Stanowi on także podstawę życia społecznego. Gospodarowanie ciałem i duszą jest niczym innym jak tylko współdziałaniem. W dniu, w którym społeczeństwo zostanie zorganizowane - począwszy od szkoły - współdziałanie to dojrzeje do potrzeby uzewnętrzniania własnych radości i smutków w formie działań zespołowych takich, jakie praktykowali starożytni Grecy" (Jaques-Dalcroze 1992: 82). Porządek rzeczy, czyli pewien rytm odnajduje się w naturze i dlatego Jaques-Dalcroze twierdził, że wychowanie rytmiczne jest naturalne i jest sztuką, gdyż jego podstawą jest rytm muzyczny, a muzyka jest sztuką. Rousseau sztuką czyni wychowanie ogólne: „Wychowanie pochodzi od natury (...), wychowanie jest przeto sztuką” (Rousseau 1955a: 9). Można znaleźć jeszcze inną analogię, w której Rousseau pochwala wszystko, co naturalne, a Jaques-Dalcroze wskazuje na rytm jako naturalne zjawisko przyrody (powtarzalność pór roku, cykliczność dnia i nocy, rytm bicia serca itp.).

${ }^{15}$ Zauważyć można zbliżenie terminu muzykalność stosowanego przez Jaques-Dalcroze'a do muzykalności definiowanej przez B. Tiepłowa - zdolności do emocjonalnego przeżywania muzyki, której podstawą jest poczucie tonalne, zdolność do wyobrażeń słuchowych i poczucie rytmu muzycznego (Lewandowska 1978). 


\section{Myśl 2. Matka jest naturalną opiekunką dziecka i inicjatorką jego pierwszych doświadczeń muzycznych}

Pierwsze kontakty dziecka z naturą, w tym z dźwiękami akustycznymi i muzycznymi, mogą mieć miejsce już w pierwszych dniach jego życia (Choksy i in. 1986, Danecka-Szopowa 1960, Gloton, Clero 1976, Harwas-Napierała, Trempała 2004, Lewandowska 1978, Manturzewska, Kotarska 1990, Shuter-Dyson, Gabriel 1986). Od narodzin biologicznie najbliższą dziecku osobą jest jego matka, która zapewnia intensywne doznania ważne dla rozwoju intelektualnego i fizycznego dziecka, dba o obecność i jakość bodźców stymulujących także jego muzyczny rozwój. Dlatego zarówno Jan Jakub Rousseau, jak i Emil Jaques-Dalcroze uważają taką sytuację za naturalną i oczywistą. Zatem udzielają oni wskazówek matkom, od którego momentu życia dziecka i jak powinny postępować, by uwrażliwiać dzieci na muzykę ${ }^{16}$ : „Matka musi dziecko już od kołyski nieustannie wprowadzać we wszystko. Musi stać się dla niego wzorem, obserwować jego reakcje, kontrolować je i odpowiednio modelować - bez surowości, poprzez zabawę" (Jaques-Dalcroze 1992: 119). W innym miejscu Jaques-Dalcroze wskazuje matkom, że w wychowaniu swych małych dzieci powinny mieć na uwadze to, by nauczyć je oceniania niuansów muzycznych, gdyż dziecko potrafi słuchać muzyki, tylko brakuje mu narzędzi do wypowiadania sądów na jej temat. Zatem to, co dotyczy rozróżniania dynamiki, agogiki, barwy i rejestrów instrumentów muzycznych (a także rozwija myślenie), matka powinna u dziecka regularnie ćwiczyć. Emil Jaques-Dalcroze wskazuje przy tym na istotę jej bliskiego i niewymuszonego związku z dzieckiem, który gwarantuje pożądany efekt: „Dlatego też matka, jeśli potrafi oddziaływać w sposób systematyczny (...) może odegrać szczególną rolę w zainteresowaniu go muzyką i pokochaniu jej” (podkreślenie Jaques-Dalcroze'a) (Jaques-Dalcroze 1992: 27).

Zdaje się to samo dostrzegać Rousseau, gdy przypisuje Zofii, bohaterce swojego traktatu Emil, czyli o wychowaniu - przymioty, które określa jako talenty, a właściwie zamiłowanie, gdyż Zofia nie potrafi czytać nut, czyli nie zna znaków umożliwiających odtwarzanie muzyki, za to prawdopodobnie potrafi improwizować wokalnie, grać na klawikordzie

\footnotetext{
${ }^{16}$ W czasach, w których żyli Rousseau i Jaques-Dalcroze, aktywność muzyczna kobiet była naturalna śpiewanie, tańczenie czy granie na instrumencie muzycznym należało do „dobrego tonu”, było elementem wychowania dziewcząt z zamożniejszy domów. Stąd według obu autorów, adresatki ich przemyśleń matki, które mają nawet tylko elementarną wiedzę muzyczną i takież muzyczne umiejętności, w sposób świadomy powinny spożytkować je przy wychowaniu dziecka, by niezależnie od jego płci uwrażliwiać je na muzykę, prowokować do kontaktu z muzyką. Zadania, jakie stawiają przed matkami zarówno Rousseau, jak i Jaques-Dalcroze, wymagają umiejętności, które są kształcone, z którymi człowiek nie przychodzi na świat. Zdobyta wiedza muzyczna (na której braki u Zofii wskazuje J.J. Rousseau, ale podkreśla umiejętności: sprawne granie na klawikordzie oraz szczególną zdolność do improwizowania muzyki), wraz z muzyczną praktyką, zdają się w rozumieniu obu muzyków wystarczające, by uwrażliwiać dziecko na elementy muzyki. Z oczywistych powodów (wymienię tylko m.in. odmienny sposób wychowania i kształcenia dzieci w XXI wieku) nie należy zakładać, że są to „wytyczne” dla współczesnych matek, a raczej tylko przypomnienie, jak ważną rolę muzyka może spełniać w wychowaniu dziecka, że są to wartości, na które wskazywało wielu myślicieli w przeszłości (także w czasach starożytnych).
} 
i poruszać się krokiem tanecznym ${ }^{17}$. Jeżeli matka ma być tą osobą, która jeszcze przed nauczycielem zewnętrznym (spoza rodziny) ma rozwijać wrażliwość muzyczną i rozwijać zmysły (słuch, dotyk, wzrok), to dostrzegamy, jakie zadania stawia przed przyszłymi matkami Rousseau, opisując umiejętności tej bohaterki: „Zofia ma wrodzone talenty, wie o tym i nie lekceważy ich. Lecz ponieważ nie miała dotąd okazji ich rozwinąć, zadowala się tym, że mając piękny głos nauczyła się dobrze i ładnie śpiewać; lekko, zgrabnie i z gracją przebierać drobnymi nóżkami i wszystkie rodzaje ukłonów w różnych sytuacjach wykonywać bez skrępowania i pewnie. Zresztą jedynym jej nauczycielem śpiewu był ojciec, jedyną mistrzynią tańca - matka. Organista z sąsiedztwa dał jej kilka lekcyj gry na klawikordzie, którym odtąd zajęła się sama. Z początku dbała o to tylko, aby najefektowniej położyć białą rękę na czarnych klawiszach, potem zaczęła znajdować, że dźwięk jej głosu staje się bardziej miękki, jeśli towarzyszy mu suchy i ostry ton klawikordu. Stopniowo jęło przychodzić zrozumienie harmonii; w miarę dorastania coraz lepiej odczuwała czar ekspresji i wreszcie polubiła samą muzykę. Lecz jest to raczej upodobanie niż talent; nie umie jeszcze dotąd grać arii z nut!” (Rousseau 1955b: 276). J.J. Rousseau wyraźnie mówi o ogromnej muzykalności Zofii ${ }^{18}$, która umie to, co powinno być przydatne matce w wychowaniu dziecka, w zbliżeniu go do muzyki. Jest to przykład, że zajmowanie się muzyką nie jest chwilowe, to proces trwający nieprzerwanie, jest częścią wychowania i na tym między innymi upływa całe dzieciństwo i młodość człowieka. To nazywa naturalnym wychowaniem, w którym stopniowo poznaje się muzykę, rozsmakowuje się w niej. Harmonijny rozwój zdolności następuje w czasie. Podobnie jest u Jaques-Dalcroze’a, gdy wyznacza cel swojej rytmice: „W rzeczywistości, celem nowego nauczania jest zapewnienie równowagi pomiędzy wszystkimi rodzajami zdolności"19 (Jaques-Dalcroze 1992: 124). Zdolności te rozwijają się, gdy uaktywni się zmysły dziecka: słuch, wzrok, dotyk oraz aktywności, jak śpiewanie i ekspresje ruchową. Jan Jakub Rousseau podkreśla znaczenie zmysłów: „Pierwszymi władzami, które powstają w nas i doskonalą się, są zmysły. One też kształcone być winny przede wszystkim, a tymczasem zapomina się o nich lub lekceważy najbardziej. Ćwiczyć zmysły nie znaczy to jedynie używać ich, ale uczyć się z ich pomocą dobrze zdawać sprawę" (Rousseau 1955a: 149). To właśnie poprzez zmysły uruchamiane jest ciało. Słyszana muzyka, dźwięk, porusza system mięśniowy, łączy intelekt z ruchem fizycznym (mikro i makro ruchem). Chęć śpiewania piosenki wywołuje ruchy narządu mowy (mięśnie oddechowe, struny głosowe, mięśnie twarzy, warg). Emil Jaques-Dalcroze podkreśla w Pismach to, co jest znane specjalistom w zakresie emisji głosu i mowy: „Sam tylko fakt myślenia o melodii (podkreślenie E. Jaques-Dalcroze’a) wywołuje w gardle ruchy mięśniowe niezbędne do jej wykonania. Tak więc prawidło-

\footnotetext{
${ }^{17}$ Zarówno termin talenty, jak i zamiłowanie są użyte przez J.J. Rousseau.

${ }^{18}$ Pojęciom talenty, zdolności, muzykalność używanym przez Rousseau można przypisać znaczenie bardziej potoczne, gdyż współcześnie mają one swoje głębokie uzasadnienie w psychologii muzyki (np. talentem wrodzonym określa umiejętność grania na instrumencie, a jest to wyuczona czynność).

${ }^{19}$ E. Jaques-Dalcroze pokazuje, że jego rytmika rozwija zdolności nie tylko muzyczne.
} 
wemu rozwojowi słuchu muzycznego dziecka powinno towarzyszyć kształcenie głosu" (Jaques-Dalcroze 1992: 27).

Podobnie Rousseau organ słuchu łączy z głosem, jak Jaques-Dalcroze. Wymienia jego rodzaje i wskazuje ich znaczenie: głos mówiący (artykułowany), śpiewający (melodyjny), patetyczny (intonacja - jest ożywieniem śpiewu i słowa). „Doskonała muzyka jest ta, która łączy najlepiej te trzy głosy. Dzieci niezdolne są do tej muzyki i śpiew ich pozbawiony jest zawsze uczucia" (Rousseau 1955a: 174). Rousseau daje prymat śpiewaniu jako tej formie aktywności, która najbardziej w muzyce przekazuje emocje. Jaques-Dalcroze pozostawia w równowadze śpiewanie i ruch, przy czym dla pełni interpretacyjnych możliwości dzieci wysuwa myśl o wartości ruchu jako środka wyrazu. Podkreśla, że nie jest wartościowy ruch bez idei, bez myślenia o nim, o nadaniu mu kierunku, siły czy czasu trwania. Jeżeli jednak wytwarzane są automatyzmy ruchowe, to tylko po to, by myślenie przekierować na wyrazowość ruchu. W ćwiczeniach rytmicznych Jaques-Dalcroze dostrzega ścisły związek pomiędzy pracą mózgu i reakcjami ruchowymi, więc jeżeli powodują one akcelerację rozwoju umysłowego i fizycznego, to należy zadbać o to, by stały się częścią wychowania ogólnego człowieka od momentu jego narodzin. Zadania takie wyznacza matkom, opiekunkom dziecka, a następnie - nauczycielom.

\section{Myśl 3. Dziecko powinno być samodzielne w myśleniu (także w myśleniu muzycznym), samo może odkrywać świat (świat muzyki) i prawa nim rządzące (np. zasady muzyki, sposób interpretowania muzyki), nauczyciel ma tylko je w tym wspierać}

„Jeżeli głowa twoja zawsze kieruje ramieniem dziecka, własna jego głowa staje mu się zbyteczna" (Rousseau 1955a: 128). Jan Jakub Rousseau pisze w traktacie Emil, że nie należy dziecku narzucać własnych poglądów, gdyż wówczas nigdy nie osiągnie ono samodzielności w myśleniu, w ocenianiu i wydawaniu sądów. Warto podpowiadać i kierować, ale nie zastępować dziecka w podejmowaniu decyzji. Myśl ta w czasach oświeceniowych była rewolucyjną. Po prawie dwóch stuleciach Jaques-Dalcroze zauważył, że także w edukacji muzycznej, wówczas, gdy pozwoli się dziecku na eksperymentowanie z muzyką, śpiewanie, poruszanie się zgodnie z jego własnymi odczuciami, dziecko zacznie odkrywać prawidła rządzące muzyką. Bardziej samodzielnie będzie wypowiadało się na jej temat, gdy myśli będą powiązane z praktyką wykonawczą, z dziecięcą aktywnością muzyczną.

Ważnym krokiem w osiąganiu samodzielności muzycznej przez dziecko stała się improwizacja. Jej znaczenia w kształceniu muzycznym dotąd nie doceniano, co więcej nie dopuszczano myśli, że improwizować muzycznie może dziecko. Tymczasem kierowane improwizacje wokalna i ruchowa, które są wpisane w Dalcrozowską rytmikę, przyczyniają się do zaciekawienia i następnie zainteresowania dziecka muzyką. Dziecko, które rozpoczyna naukę gry na fortepianie, według Jaques-Dalcroze'a ma ją rozpoczynać od pierwszych ćwiczeń w zakresie improwizacji, ale ich celem jest rozbudzenie ciekawości samymi powstającymi dźwiękami i pobudzenie wyobraźni. Krytycznie odnosi się do czysto technicznej gry i mechanicznie wydobywanych dźwięków: „Prawdziwym non- 
sensem jest rozpoczynanie przez dziecko nauki gry na fortepianie, zanim nie okaże ono swojej wrażliwości na rytm oraz zdolności rozpoznawania dźwięków” (Jaques-Dalcroze 1992: 30). Przygotowaniu do gry na fortepianie miały służyć zabawy, w których dziecko poszukuje palcami na klawiaturze muzyki - dźwięków, które wcześniej zaśpiewało i wówczas zaczyna muzycznie myśleć. Myślenie muzyczne dziecka rozwija się najbardziej dynamicznie, gdy łączy się praktykę wykonawczą z wiedzą teoretyczna, przy czym praktyka powinna zawsze wyprzedzać teorię. Praktyka, to pierwsze dziecięce zabawy muzyczne organizowane, jak sugeruje Jaques-Dalcroze, w domu przez matkę ${ }^{20}$. Powoływał się on przy tym na słowa Montaigne`a: „Prawdziwa edukacja muzyczna zaczyna się w ramionach matki” (Jaques-Dalcroze 1992:121). I wyjaśniał powody tak wcześnie wprowadzanych zabaw muzycznych: „Tę naukę przez zabawę trzeba naturalnie uzupełniać ćwiczeniami układu nerwowego, zmysłu analizy i umiejscawiania w przestrzeni. Jest bardzo wiele zabaw, które stanowiąc dla dziecka rozrywkę, uczą je podświadomie łączyć wrażenia słuchowe z wzrokowymi i dotykowymi" (Jaques-Dalcroze 1992: 121). Jak widać, nie tylko względy czysto muzyczne Jaques-Dalcroze miał na uwadze, ale właśnie to, że dziecko ćwiczy pod okiem matki, ona wspiera je, naprowadza, ale nie zastępuje w podejmowaniu decyzji. Emil Jaques-Dalcroze zauważa, że pierwotne dla dziecka jest naśladownictwo dorosłych, ale to szybko staje się bazą dla jego własnych twórczych rozwiązań: „Większość ludzi ma od dzieciństwa skłonność do naśladownictwa; nauczyciel nie musi więc uczyć ich czegoś, co potrafią robić instynktownie. Jego rolą jest sugerowanie i ukierunkowanie, a nie nakazywanie. Na przykład szczegóły wykonania utworu muzycznego powinien zawsze odkrywać sam uczeń" (Jaques-Dalcroze, 1992: 117). Tu myśli Emila Jaques-Dalcroze'a i Jana Jakuba Rousseau zbiegają się w tym samym punkcie. Można przypuszczać, że praktyczne rozwiązania twórcy rytmiki w pracy z dzieckiem i myśli oświeceniowego filozofa odnośnie do wychowania zapewne miały swój początek w ich własnych doświadczenia z dzieciństwa ${ }^{21}$, jak również w ich uważnych obserwacjach małych dzieci podczas zabawy i nauki.

\section{Myśl 4. Dziecko powinno znajdować przyjemność i radość w uczeniu się (uczeniu się muzyki)}

Jan Jakub Rousseau w swym traktacie „Emil” wielokrotnie wskazywał, że dziecka nie powinno przymuszać się do poznawania, do systematycznej nauki inaczej, jak poprzez praktykę. Jego „wychowanie naturalne” opierało się właśnie na tej zasadzie, a w każdym aspekcie wychowania, także w kontakcie z muzyką, dziecko powinno odnaleźć radość

\footnotetext{
${ }^{20}$ Jaques-Dalcroze wskazywał, jak ważna jest rola matki, która „od kołyski może oswajać dziecko z muzyką", Pisma wybrane, s. 121.

${ }^{21}$ Rousseau muzykę, śpiew jego ciotki, który towarzyszył mu od pierwszych dni po narodzinach, zapamiętał jako przyjemne doświadczenia. Nie był przymuszany do nauki muzyki, nauki gry na instrumencie. Ciekawość spowodowała, że sam zaczął studiować muzykę i to zapewne wyznaczyło drogę do pokazywania wagi samodzielności dziecka, samodzielności umysłowej z możliwością wyboru, a nie przymusu uczenia się.
} 
i przyjemność poprzez „,sztukę działania”. Aktywność dziecka i eksploracja świata i muzyki powoduje, że dziecko zaspokaja własną ciekawość na drodze poznania zmysłowego i umysłowego, co staje się faktem w rytmice: „Cała metoda opiera się na zasadzie, która mówi, że praktyka powinna poprzedzać studia teoretyczne i że nie należy uczyć dzieci reguł zanim same nie doświadczą one zjawisk, które przyczyniły się do ustalenia tych reguł. Poza tym podstawową rzeczą $\mathrm{w}$ takim nauczaniu powinno być sprawianie, by dziecko umiało wykorzystywać wszystkie swoje możliwości” (Jaques-Dalcroze 1992: 40). Interpretując te słowa, należy sądzić, że praktyka poprzedzająca teorię, to może być zabawa dydaktyczna.

Emil Jaques-Dalcroze, który czerpał z doświadczeń sobie współczesnych pedagogów i psychologów, podawał za wzór dla swojej pracy pedagogicznej m.in. przedszkole M. Montessorii, w którym dziecko muzykę poznaje poprzez zabawę (Jaques-Dalcroze 1992). Rezultaty obserwacji wykorzystywał w swojej pracy z dziećmi i znajdowały one odbicie w jego holistycznym podejściu do wychowania muzycznego. Zabawa i radość uczenia się powinna stymulować dziecko do poszukiwań reguł działania, do wiedzy: „Wpływ rytmu muzycznego ujawnia się od pierwszych zajęć w przedszkolu. Duch i ciało zaczynają wspólnie działać. Ciekawość pobudza instynkt" (Jaques-Dalcroze 1992: 124).

Aby nauka przez zabawę była dla dziecka radosnym doświadczeniem, to jeszcze w domu pod opieką matki, przed pójściem do przedszkola powinno ono doznawać przyjemnych chwil z muzyką. Pamiętał o tym Jan Jakub Rousseau, przestrzegając dorosłych i stawiając im duże wymagania jako opiekunom i nauczycielom własnych dzieci: „Ale za dużo o muzyce; ucz jej, jak chcesz, byleby była zawsze rozrywką tylko" (Rousseau 1955a: 176). Wskazywał on, że uczenie dzieci czytania nut, śpiewania solfeżu i przekazywanie zasad muzyki nie powinno zanudzić dziecka, by nie straciło ono radości tej nauki.

Jak można zauważyć, zainteresowanie muzyką, potrzeba obcowania z nią, traktowanie kontaktów z muzyką w kategorii przyjemności, akcentowane jest przez obu Szwajcarów. Zauważyli oni, iż pozytywne nastawienie dziecka do muzyki wspiera jego wysiłek w nauce i sprzyja rozwijaniu zdolności muzycznych, najbardziej w pierwszej dekadzie życia ${ }^{22}$. Poza tym muzyka rozwija procesy myślowe, czyni wrażliwym dziecko nie tylko na samą muzykę, ale także na drugiego człowieka wówczas, gdy przewodnikiem dla dziecka jest kompetentny nauczyciel: „Talent nauczania polega na tym, by uczeń znajdował przyjemność w uczeniu się" (Rousseau 1955a: 61).

\section{Zakończenie}

Jan Jakub Rousseau był myślicielem nietuzinkowym i nowatorskim, gdy wypowiadał się na temat wychowania dzieci. Zajmował stanowisko także w sprawie wychowania muzycznego i sztuki muzycznej. Niezależnie od faktu, jak on sam jest postrzegany współcześnie, jego idee (niektóre ze względu na swą kontrowersyjność), były i są inspirujące dla

${ }^{22}$ Współczesna nauka także wskazuje na ten etap w życiu dziecka jako najbardziej efektywny dla rozwijania zdolności muzycznych, np. Tiepłow, Gordon, Wierszyłowski i in. 
wielu, którzy podjęli się ich weryfikacji i/lub interpretacji. Na przełomie XIX i XX wieku były one przesłaniem i drogowskazem dla Ruchu Nowego Wychowania. Jednym z sympatyków Ruchu był Emil Jaques-Dalcroze, który zetknął się z dorobkiem oświeceniowego wychowawcy, filozofa i muzyka, a reminiscencje jego myśli o wychowaniu muzycznym zamieszczał w swoich tekstach o rytmice, których fragmenty zostały przetłumaczone w 1992 roku na język polski i zebrane w książce pt. Pisma wybrane.

Samemu Rousseau zarzuca się, że nie był dobrym nauczycielem muzyki, ale jego spostrzeżenia wyzwalają u innych (np. u Jaques-Dalcroze'a) refleksje nad edukacją muzyczną dziecka. Wielokrotnie w kontekście muzyki i dziecka pojawia się nauczyciel, w stosunku do którego zarówno Rousseau, jak i Jaques-Dalcroze byli bardzo wymagający. Profesjonalizm nauczyciela mierzyli radością, z jaką dziecko podchodzi do nauki. I w tym miejscu warto podkreślić znaczenie tych idei (zdaje się nieobecnych w polskiej szkole) dla współczesnej edukacji muzycznej, w której nauczyciele deklarują prymat ekspresji i postaw twórczych, a w rzeczywistości realizują edukację muzyczną w tradycyjnym kształcie ${ }^{23}$, odwołującą się głównie do modelu transmisyjnego ${ }^{24}$.

Przypomnienie interesujących i, jak czas pokazuje, uniwersalnych poglądów Rousseau i Jaques-Dalcroze'a na ekspresję muzyczną, na twórcze działanie dziecka i odkrywanie muzyki jest istotne, gdyż zbyt częstym jest pogląd, że edukacja muzyczna to „zbędny dodatek” do „właściwej edukacji” dziecka ${ }^{25}$ oraz że ogólny rozwój dziecka nie będzie zubożony, gdy pozbawi się je treści szeroko rozumianej edukacji muzycznej ${ }^{26}$.

Do opracowania niniejszego tekstu wykorzystałam te idee Jana Jakuba Rousseau i Emila Jaques-Dalcroze'a, które są wzajemnie spójne i na które warto zwrócić uwagę w XXI wieku, gdyż obecny stan badań nad muzyką w życiu człowieka (nieobecnych za życia Rousseau i Jaques-Dalcroze'a) czyni je jeszcze bardziej uniwersalnymi i ponadczasowymi. Do nich odwołuję się w moich przemyśleniach i rekomenduję czytelnikowi i wszystkim, którzy uczestniczą w procesie wychowania i kształcenia dziecka.

Współczesny świat poszukuje specjalistów, zatem wartością cenioną społecznie jest eksperckość w określonej dziedzinie. Uprawianie muzyki ma korzystny wpływ na procesy poznawcze, strategie uczenia się i osiągnięcia w nauce (na co wskazują podejmowane badania np. Wilsz 2012), zatem można przypuszczać, że także na zdobywanie umiejęt-

\footnotetext{
${ }^{23} \mathrm{O}$ zaniedbaniach i zaniechaniach w polskiej edukacji muzycznej pisałam m.in. w: Ekspresja muzyczno-ruchowa jako zaniedbany obszar edukacji muzycznej dziecka. W: M. Suświłło (red.), Zaniedbane i zaniechane obszary edukacji w szkole. Wydawnictwo Uniwersytetu Warmińsko-Mazurskiego, Olsztyn 2006; Narracje studentów wczesnej edukacji i nauczycieli o ,zaprzepaszczonych” szansach uzdolnionych muzycznie dzieci. W: M. Jabłonowska (red.), Środowisko edukacyjne uczniów zdolnych. Wydawnictwo Universitas Rediviva, Warszawa 2013. W tych artykułach szerzej omawiałam różne formy aktywności muzycznej dziecka występujące w polskiej koncepcji wychowania muzycznego/ edukacji muzycznej, nie zamierzałam tego czynić w niniejszym tekście, a przywołać jedynie wątek związany z rytmiką.

${ }^{24}$ Idee oświeceniowe Rousseau i te sformułowane przed stu laty przez Jaques-Dalcroze’a można odnieść także do kształcenia muzycznego najmłodszych w szkolnictwie artystycznym.

25 „Właściwa edukacja” - czyli wszystkie pozostałe rodzaje edukacji określone w podstawie programowej dla edukacji wczesnoszkolnej.

${ }^{26}$ Doświadczenia terapeutów - pedagogów specjalnych i muzykoterapeutów podważają takie myślenie.
} 
ności i wiedzy przydatnej ogólnie ekspertom - wszystkim, nie tylko muzycznym. Ale zanim ktoś stanie się ekspertem, jest po prostu dzieckiem. Badania pokazują, że u dzieci rozwój procesów poznawczych dzięki ich aktywności muzycznej jest bardziej dynamiczny, szczególnie gdy następuje transfer pozytywny z ćwiczeń muzycznych na inne sytuacje życiowe (Wilsz 2012).

Uprawianie muzyki połączone ze zdobywaniem wiedzy (w większym stopniu u osób z wrodzonymi uzdolnieniami muzycznymi) bardzo rozwija pamięć muzyczną i ogólną (Hankała 2012), akceleruje rozwój procesów poznawczych. Rozwija sprawność fizyczną i motorykę ciała (Kilińska-Ewertowska 1978), a także koordynacje słuchowo-wzrokowo-ruchowe. Usprawnia w przypadku różnego typu zaburzeń i niesprawności (stosowana jest $\mathrm{w}$ muzykoterapii). Niektórzy badacze podkreślają istotny związek zdolności matematycznych i językowych z muzycznymi, a także edukacji muzycznej z rozwojem umiejętności przestrzenno-czasowych, czyli tego wszystkiego, co powinno być rozwijane lub kształcone u dziecka ${ }^{27}$. Edukacja muzyczna ze swym programem, w którym ważna jest dziecięca ekspresja i osobiste zaangażowanie, ma dobroczynny wpływ na bardzo małe dzieci, gdyż następuje w tym okresie silny rozwój połączeń nerwowych i dodatkowe bodźce mogą wpływać u nich na rozwój inteligencji ogólnej (stąd programy edukacyjne Kodaly'a, Orffa, Dalcroze'a, Suzuki, Gordona przez tak wiele lat są wykorzystywane na całym świecie - a Dalcrozowska rytmika już sto lat). Praktyka muzyczna stwarza dziecku szansę bycia samodzielnym w działaniu i myśleniu (także w myśleniu muzycznym), odkrywaniu świata muzyki i praw nim rządzących (np. zasady muzyki, sposób interpretowania muzyki). Zadaniem nauczyciela jest bycie blisko dziecka i wspieranie, by stawało się samodzielne i by uczyło się z radością i przyjemnością.

Muzykowanie (aktywność wokalna, ruchowa, instrumentalna) związane jest z wykształconym zmysłem słuchu, a jego rozwój już w okresie prenatalnym ma istotne znaczenie dla funkcjonowania tego zmysłu w całym późniejszym życiu człowieka. W tym to okresie kształtują się receptory muzyczne i powstają pierwsze reakcje dziecka sensoryczno-motoryczne na muzykę (Manturzewska, Kamińska 1990). Noworodek bezbłędnie rozpoznaje głos matki, a szczególnie dla dziecka korzystny jest jej śpiew (Manturzewska, Kamińska $1990^{28}$ ). Dziecko po urodzeniu jest bardziej wrażliwe na tę muzykę, której matka z przyjemnością słuchała w okresie ciąży (Campbell 2003, Thompson 2009 za: Głuska 2012). Zarówno w okresie prenatalnym, jak i po urodzeniu słyszany język werbalny, jak i muzyka pozwalają dziecku na nabywanie kompetencji językowych i muzycznych w sposób naturalny, poprzez naśladownictwo (Suzuki 2010: 37, Vasta, Marshall, Scott 1995, Sloboda 2002). Zanim dziecko osiągnie wiek przedszkolny, dzięki odpowiedniej stymulacji muzycznej ze strony najbliższych, szczególnie matki (podkreślenie autorki), która najwięcej czasu spędza z dzieckiem, następuje wzrost wokalizacji, zwracania się ku słyszanej muzyce i przysłuchiwaniu się jej (Manturzewska, Kamińska 1990, Sloboda 2002),

\footnotetext{
${ }^{27}$ N. Wilsz opisuje badania Vaughn, Brochard, Dufour, Despres, Hetland i innych w artykule Czy uprawianie muzyki ma korzystny wplyw na procesy poznawcze, strategie uczenia się i osiagnięcia w nauce? ${ }^{28}$ Autorki opisywały badania DeCasper, Fifer z 1980 roku.
} 
a także reagowanie ruchem na muzykę (takie reakcje mogą sugerować wrażliwość dziecka na rytm muzyczny). Zachęcanie dzieci do muzykowania, a przez to wykorzystywanie muzyki dla bardziej intensywnego rozwoju w całym życiu także jest rolą matki. To ona inicjując zabawy muzyczne, pierwsza stymuluje słyszenie muzyczne i rozwój zdolności muzycznych, potrzebę kontaktu dziecka z muzyką. W następnym okresie życia dziecka tę rolę i zadania przejmuje nauczyciel w przedszkolu i szkole.

W tym miejscu powracam do myśli Jana Jakuba Rousseau i Emila Jaques-Dalcroze'a. Pierwszy intuicyjnie wyczuwał potrzeby dziecka, drugi także, ale dodatkowo podpierał się badaniami naukowymi swojej epoki, które w jakiejś części dawały odpowiedź na pytania dotyczące rozwoju dziecka. Myśli Rousseau i Jaques-Dalcroze’a sformułowane w XVIII i XX wieku były bardzo postępowe i tak je postrzegam w wieku już dwudziestym pierwszym.

\section{Literatura}

Bem K, Makowski J. (2009), Kalwin Reformator, „Polityka” z dn. 4 listopada 2009. http://www. polityka.pl/tygodnikpolityka/historia/297191,1,kalwin-reformator.read (dostęp 15.10.2015).

Brzozowska-Kuczkiewicz M. (1991), Emil Jaques-Dalcroze i jego rytmika. Warszawa, WSiP.

Choksy L., Abramson R.M., Gillespie A.E., Woods D. (1986), Teaching music in the twentieth century. New Jersey, Prentice Hall.

Danecka-Szopowa K. (1960), Wybrane zagadnienia z psychologii muzyki. Materiały Pomocnicze COPSA.

Gloton R., Clero C. (1976), Rozwój aktywności twórczej. Warszawa, WSiP.

Głuska A.A. (2012), Rozwój zmysłu słuchu i muzycznej wrażliwości od okresu prenatalnego do wieku przedszkolnego. W: E. Czerniawska (red.), Muzyka i my. O różnych przejawach wptywu muzyki na rozwój człowieka. Warszawa, Wydawnictwo Difin.

Górny T. (2012), Zwiąki retoryki i muzyki - Kantata Christ Lag in Todesbanden Jana Sebastiana Bacha. https://www.deepdyve.com/lp/de-gruyter/zwi-zki-retoryki-i-muzyki-kantata-christ-lagin-todesbanden-jana-rhJmCvfqfZ (dostęp 15.10.2015).

Hankała A. (2012), Pamięć ekspertów muzycznych. W: E. Czerniawska (red.), Muzyka i my. O różnych przejawach wpływu muzyki na rozwój człowieka. Warszawa, Wydawnictwo Difin.

Harwas-Napierała B., Trempała J (2004), Psychologia rozwoju człowieka. Charakterystyka okresów zycia człowieka. Warszawa, Wydawnictwo Naukowe PWN.

Jaques-Dalcroze E. (1992), Pisma wybrane. Warszawa, WSiP.

Kilińska-Ewertowska E. (1978), Logorytmika. Lublin, Wydawnictwo UMCS.

Lewandowska K.(1978), Rozwój zdolności muzycznych ucznia. Warszawa, WSiP

Rousseau J.J. (1955a), Emil, czyli o wychowaniu. T. 1. Wrocław, Wyd. PAN.

Rousseau J.J. (1955b), Emil, czyli o wychowaniu. T. 2. Wrocław, Wyd. PAN.

Rousseau J.J. (1962), Wyznania. T. 1. Wrocław-Warszawa-Kraków, Zakład Narodowy im. Ossolińskich.

Rousseau J.J. (1978), Wyznania. (Wybór). Wrocław-Warszawa-Kraków-Gdańsk, Zakład Narodowy im. Ossolińskich.

Shuter-Dyson R., Gabriel C. (1986), Psychologia uzdolnienia muzycznego. Warszawa, WSiP. 
Skowron Z. (2010), Myśl muzyczna Jeana Jacques'a Rousseau. Warszawa, Wydawnictwo UW.

Sloboda J.A.(2002), Umyst muzyczny. Poznawcza psychologia muzyki. Warszawa, Wydawnictwo AMFC.

Suzuki S. (2010), Karmieni miłościq. Warszawa, Centrum Uzdolnień Metodą Suzuki.

Wilsz N. (2012), Czy uprawianie muzyki ma korzystny wplyw na procesy poznawcze, strategie uczenia się i osiagnięcia w nauce? W: E. Czerniawska (red.), Muzyka i my. O różnych przejawach wpływu muzyki na rozwój człowieka. Warszawa, Wydawnictwo Difin.

Vasta R., Marshall M.H., Scott A.M. (1995), Psychologia dziecka. Warszawa, WSiP. 